\title{
Preliminary evaluation of a short rotation forestry poplar biomass supply chain in Emilia Romagna Region
}

\author{
L. Pari, ${ }^{1}$ Massimo Brambilla, ${ }^{2}$ V. Civitarese, ${ }^{1}$ C. Bisaglia ${ }^{2}$ \\ ${ }^{1}$ Consiglio per la Ricerca e la Sperimentazione in Agricoltura, Unità di Ricerca per l'Ingegneria \\ Agraria, Monterotondo (Roma), Italy; ${ }^{2}$ Consiglio per la Ricerca e la Sperimentazione in Agricoltura, \\ Unità di Ricerca per l'Ingegneria Agraria, Laboratorio di Treviglio (BC), Italy
}

\begin{abstract}
Woody Biomasses (from agriculture and forestry activities) are among the most promising renewable energy sources. Current literature describes woody biomass feedstock supply chains supporting biofuels and utilities industries: the potentially productive land area overheads required for biomass production may results in a complex logistic within the whole chain. Its effective enhancement requires significant changes in the logistics environment of energy plants for sustainable energy production and the sequence-dependent procurement chains for biomasses furthermore complicate these changes. According to this, optimizing harvesting and supplying operations turns out to be strategic within the framework of the current energy policy. In this work we present a case study carried out monitoring 57 short rotation forestry (SRF) production sites placed in Emilia Romagna Region, Northern Italy, all supplying the harvested biomass
\end{abstract}

Correspondence: Massimo Brambilla, Consiglio per la Ricerca e la Sperimentazione in Agricoltura, Unità di Ricerca per l'Ingegneria Agraria, Laboratorio di Treviglio, via Milano 43, 24047 Treviglio (BG), Italy.

Tel./Fax.: +39.0363.49603

E-mail: massimo.brambilla@entecra.it

Keywords: SRF biomass harvesting optimization, transport costs.

Contributions: the authors contributed equally.

Conflict of interests: the authors declare no potential conflict of interests.

Conference presentation: this paper was presented at the 10th AIIA Conference: "AIIA13 - Horizons in agricultural, forestry and biosystems engineering”, Viterbo, University of Tuscia, Italy, on September 8-12, 2013.

Funding: the work was supported by the SUSCACE project (Scientific Support to Agricultural Conversion towards Energy Crops).

Acknowledgments: the Authors acknowledge the role of the "SUSCACE" Project (Scientific Support to Agricultural Conversion towards Energy Crops) for funding the study.

CC Copyright L. Pari et al., 2013

Licensee PAGEPress, Italy

Journal of Agricultural Engineering 2013; XLIV(s2):e74

doi:10.4081/jae.2013.s2.e74

This article is distributed under the terms of the Creative Commons Attribution Noncommercial License (by-nc 3.0) which permits any noncommercial use, distribution, and reproduction in any medium, provided the original author(s) and source are credited. to the same biomass power plant placed in the province of Ravenna (Italy). The overall average yield of these sites was 55 t/ha, the site surfaces ranged from 0.3 to 20 hectares and the distance from the power plant ranged between 8.2 to $102 \mathrm{~km}$ with one production site only within $10 \mathrm{~km}$ from the power plant. Harvest and transport costs were calculated according to two different harvesting scenarios: $i$ ) single phase harvesting (one cutting/chopping machine + tractors and trailers); ii) double phase harvesting (cutting/mowing machine followed after 80 days by chopping machine + tractors and trailers). Results show that, according to the first scenario, at increasing distances overall harvesting and transport costs ranged from 8.9 to $21.0 \pm 1.3 € /$ t (average \pm standard deviation), while, with reference to the second scenario, they increased from 10.3 to $23.8 \pm 1.5 € / \mathrm{t}$ with the transportation costs accounting from 16 to almost $70 \%$ of the total costs.

\section{Introduction}

The rises of fossil fuel derived energy prices, and the increasing environmental concern, encourage the use of alternative and renewable energy sources as woody biomasses (Goldstein, 2006): low carbon power sources whose energy exploitation has the advantage that the emitted greenhouse gases (GHG) amounts are the same of those absorbed during the growth phase (Dubuisson and Sintzoff, 1998; Walle et al., 2007; Djomo et al., 2011).

Short rotation forestry (SRF) programs, made these woody fuel sources widely available allowing increases in production quality maintaining the competitiveness of the production costs: as far as woody fuel quality is concerned studies pointed out the importance of proper storage and handling of these biomasses (Lehtikangas, 2000; Jirjis, 2001; Lehtikangas, 2001; Pettersson and Nordfjell, 2007; Noll et al., 2010) and production management criteria were addressed as way to maintain and increase the sustainability of this production (Cherubini and Strømman, 2011; Stolarski et al., 2011; GonzálezGarcía et al., 2012). With particular reference to harvesting operations, one recent study of Fiala and Bacenetti (2012) pointed out, with reference to poplar trees, how plantation characteristics strongly influence machine productivity together with biomass transport system efficiency introducing a big tricky point of this energetic sector: biomass production and transportation account for a significant part of the whole bioenergy costs (Zhang et al., 2005) affecting plants' profitability, which is known to be highly geographically dependent (Noon and Daly, 1996). Transporting loose comminuted biomass is, at the moment, the most effective method for biomass supplying provided that close coordination of the transportation fleet is arranged (Spinelli and Hartsough, 2006).

Transportation costs from the sources to the energy plants take a significant proportion of the overall production costs of woody biomasses: hauling distance, load bulk density and delivered material 
moisture content can accounting up to 50 per cent of delivered costs (Angus-Hankin et al., 1995; Zhan et al., 2005; Pan et al., 2008). Increasing the transportation efficiency of woody biomass should significantly reduce overall production costs as well as environmental impacts (Palmgren et al., 2004). To achieve this, many models and decision systems relying on GIS approach have been developed to define planning and management strategies for the optimal logistics for energy production from woody biomass, such as forest biomass, agricultural scraps and industrial and urban untreated wood residues (Andersson $e t$ al., 1995; Frombo et al., 2008; Sang-Kyun et al., 2012). These decision support systems have been set up to select least-cost bioenergy locations when more than one bioenergy plant is present in the region and there is significant variability in biomass farm-gate price or in supply costs (Ranta, 2005; Panichelli and Gnansounou, 2008) or to facilitate the definition of sound policies and strategies based on a comprehensive perspective of the whole energy system (Mitchell, 2000; Masera et al., 2006).

Within this framework, with the final aim to assess the effective account of delivery costs on woody biomass price, we present a case study carried out monitoring short rotation forestry (SRF) production sites placed in Emilia Romagna Region, Northern Italy, all supplying the harvested biomass to the same biomass power plant placed in the province of Ravenna (Italy).

\section{Material and methods}

Fifty seven short rotation forestry biomass production sites (Figure 1) growing poplar tree (Populus spp.) or locust tree (Robinia pseudoacacia) were monitored with reference to biomass production and transport to the power plant site. According to the distance from the centralized power plant, biomass production units were divided in the following groups: $i$ ) within $10 \mathrm{~km}$; ii) from 10 to $30 \mathrm{~km}$; iii) from 30 to $40 \mathrm{~km}$; iv) from 40 to $60 \mathrm{~km} ; v$ ) from 60 to $70 \mathrm{~km} ; v i$ ) more than $70 \mathrm{~km}$.

For this production site characterization, two different scenarios (namely, "single phase harvesting" and "double phase harvesting" procedures) have been taken into account.

According to single phase harvesting scenario, biomass was harvested and chopped with a CLAAS forager (Jaguar series, CLAAS KGaA $\mathrm{mbH}$, Germany) powered by an engine rated at $372 \mathrm{~kW}$. The unit, fitted with one "GBE-1" header for SRF crop harvesting (Figure 2) cuts the stems and moves them toward the horizontal in feed rollers built into the forager unit. This harvesting-chipping machine enters the field followed by tractors with trailers or by lorries providing for chopped biomass transport to the plant site.

The double phase harvesting scenario considers two separate passes. In the first pass, a semi-trailed cut-windrower (applied to a $60 \mathrm{~kW}$ tractor at least), cuts the stems and lays them in the inter-row parallel with the advancing direction of the tractor while, in the second pass, a forage harvester equipped with a pick up head collects and chip the windrowed stems. The pick-up gathers the plants from the ground and the concomitant action of the forward moving of the tractor and of the conveyor device allows for the loading of the trees towards the feeding rolls of the chipping device and the offloading of the chips into the trailers. While the first pass is conducted in winter and during the dormant season, the second pass occurs in late spring, after the stems have been partially dehydrated. Information about production rates and costs of each of these scenario are reported in Tables 1 and 2 . For each production unit, the distance from the centralized power plant was determined and according to this, harvesting and transporting costs were calculated as follows:

$$
\begin{gathered}
\text { Harvesting Costs }(€ / t)=\frac{\text { Produced Biomass }(t)}{\text { Machine operative capacity }(\text { ha } / h)} \times \text { hourly Costs }(€ / h) \\
\text { Transport Costs }(€ / t)=\frac{\text { Time required }(h)}{\text { Lorry hourly cost }(€ / h)} \times \text { Number of required trips } x 2 \\
\text { Overall Costs }(€ / t)=\text { Harvesting costs }(€ / t)+\text { Transport Costs }(€ / t)
\end{gathered}
$$

The obtained data underwent statistical analysis by means of Minitab ${ }^{\circledR} 16$ Statistical Software (2010) to perform descriptive statistics and analysis of variance $(\mathrm{P}<0.05)$.

\section{Results}

Biomass production units of the considered scenario turn out to be quite unevenly distributed among the considered distance ranges (Figure 3), nevertheless the average surface used for biomass produc-

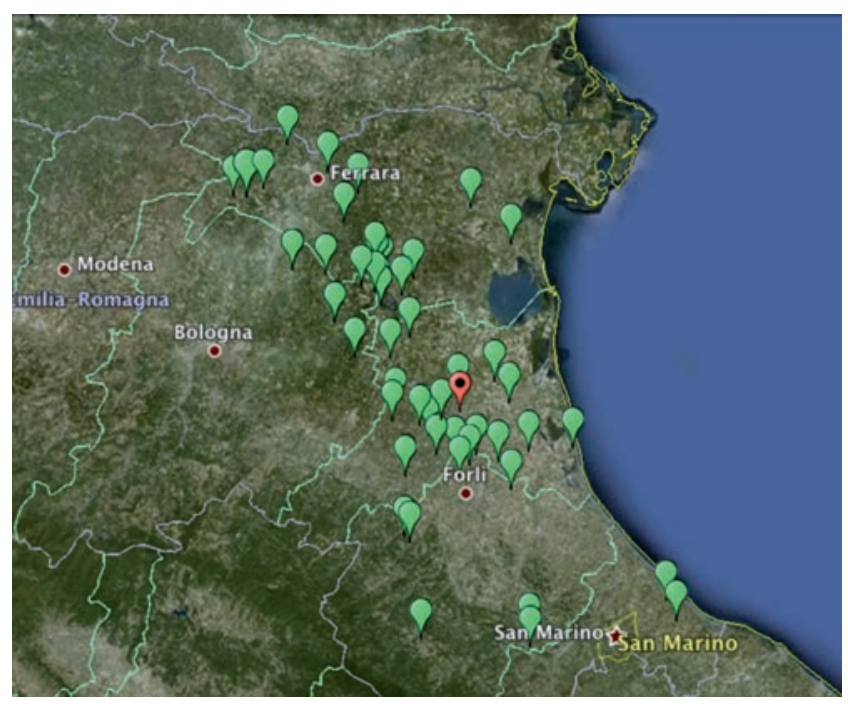

Figure 1. Geographical distribution of the biomass production sites (green markers) and of the power plant (red marker). Image from Google Earth ${ }^{\oplus}$.

tion turned out not to be significantly different (Figure 4) at $\mathrm{P}<0.05$ : as a matter of fact only one production site (whose production accounts for

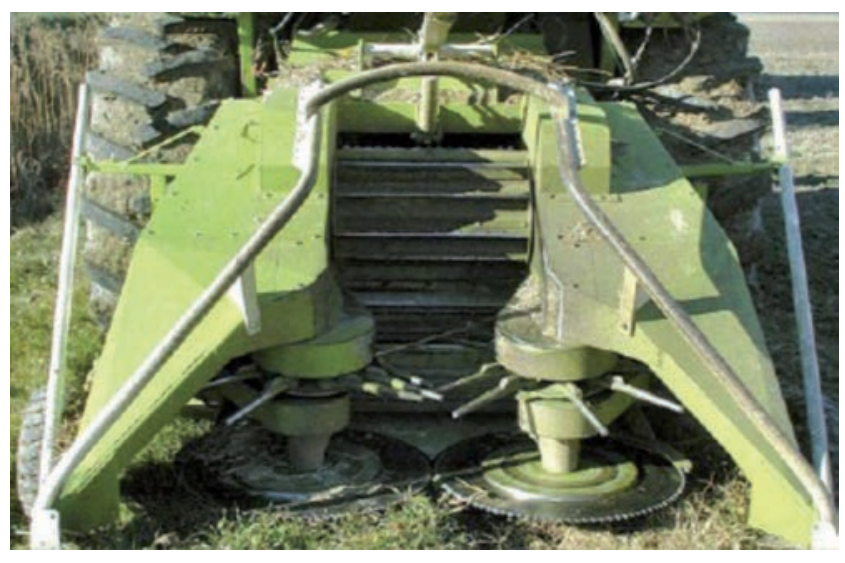

Figure 2. Particular of the GBE-1 header for SRF harvesting. 
$1.3 \%$ of the total produced biomass) is located within $10 \mathrm{~km}$ from the power plant and 4 plants only (7.0\% of the total) are placed from 10 to 30 $\mathrm{km}$ of distance while great part of them are placed more than $40 \mathrm{~km}$ far (Figure 3).

The comparison carried out on overall costs and on the per cent weight of transport costs (Table 3) shows that overall costs range from $8.92-10.26 € \mathrm{t}^{-1}$ to $20.97-23.79 € \mathrm{t}^{-1}$ increasing, as expected, at increasing distances from the power plant with similar percentage incidences of the transport costs.

If, on one hand, generally speaking, the costs related to the double phase harvesting procedure are always higher than those related to the one phase harvesting, on the other the one way ANOVA shows that in three cases only this difference turns out to be significant.

The same analysis carried out on the incidence of transport costs, shows that for production sites placed from 40 to $60 \mathrm{~km}$ and from 60 to

Table 1. Main economic and technical features of the single phase harvesting procedure.

\begin{tabular}{lc}
\hline Cutting/Chopping machine hourly cost $(€ / \mathrm{h})$ & 411.00 \\
Productivity $(\mathrm{Ha} / \mathrm{h})$ & 1.0 \\
\hline Woody Biomass Yield $(\mathrm{Mg} / \mathrm{ha})$ & 55.0 \\
Tractor + trailer hourly cost $(€ / \mathrm{h})$ & 42.00 \\
\hline Trailer maximum capacity $(\mathrm{t})$ & 0.37 \\
Tractor average speed $(\mathrm{km} / \mathrm{h})$ & 35.0 \\
\hline Lorry hourly cost $(€ / \mathrm{h})$ & 65.00 \\
Maximum capacity of the lorry $(\mathrm{t})$ & 21.00 \\
\hline Average speed of the lorry $(\mathrm{km} / \mathrm{h})$ & 50.0 \\
\hline
\end{tabular}

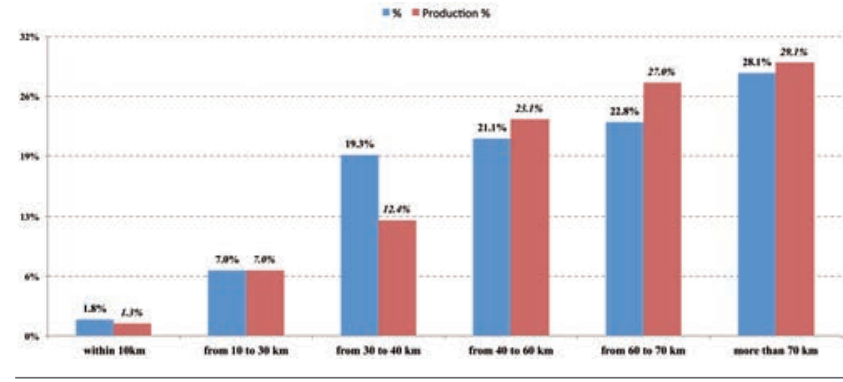

Figure 3. Distribution of the biomass production units in the distance range as percentage of their number (blue columns) and of the whole produced biomass (red columns).

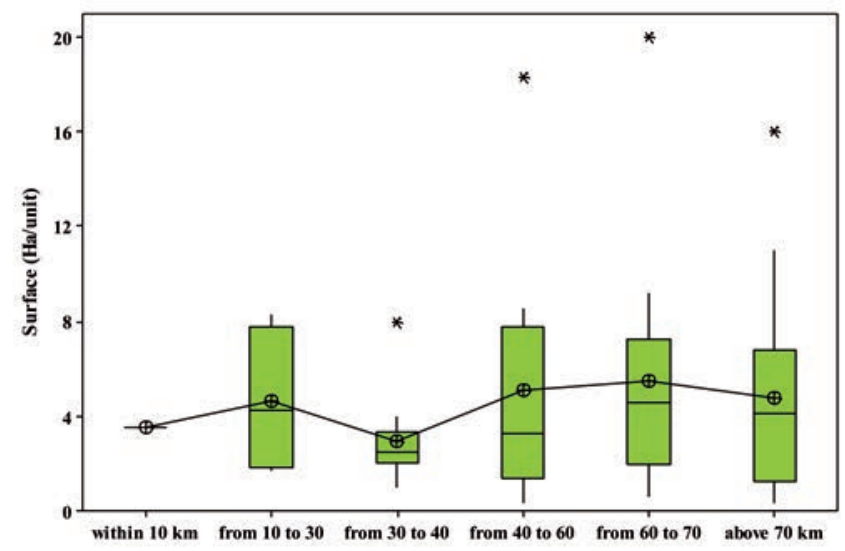

Figure 4. Boxplot chart of the average unit surface $(\mathrm{Ha} / \mathrm{unit})$ for the considered distance ranges.

Table 2. Main economic and technical features of the double phase harvesting procedure.

\begin{tabular}{|c|c|c|c|}
\hline $1^{\text {st }}$ phase: cutting and mowing & & d phase: chipping and transport & \\
\hline Cutting hourly cost $(€ / \mathrm{h})$ & 67.00 & Pick-up Hourly Cost $(€ / h)$ & 308.50 \\
\hline Operative Capacity (Ha/h) & 1.40 & Operative capacity $(\mathrm{Ha} / \mathrm{h})$ & 0.85 \\
\hline Biomass Yield (Mg/ha) & 55.0 & Biomass Yield (Mg/ha) & 46.7 \\
\hline Tractor + trailer hourly cost $(€ / \mathrm{h})$ & 42.00 & $\begin{array}{l}\text { Tractor + trailer hourly cost }(€ / \mathrm{h}) \\
\text { Maximum trailer capacity }(\mathrm{Mg}) \\
\text { Lorry for biomass transport }(€ / \mathrm{ha})\end{array}$ & $\begin{array}{c}42.00 \\
0.70 \\
73.00\end{array}$ \\
\hline
\end{tabular}

Table 3. Average harvesting and transporting overall costs as well as average per cent accounting of transport costs on the total costs. Uppercase letters indicate significant differences among mean values along the same column $(p<0.05)$, lowercase letters indicate significant differences $(p<0.05)$ between values belonging to different harvesting procedures.

\begin{tabular}{|c|c|c|c|c|c|}
\hline Distance ranges & N. of units & Single pha & e harvesting & Double ph & se harvesting \\
\hline from the power plant & & $\begin{array}{l}\text { Overall costs } \\
(€ / t)\end{array}$ & $\begin{array}{c}\text { Transport costs } \\
(\%)\end{array}$ & $\begin{array}{l}\text { Overall costs } \\
(€ / t)\end{array}$ & $\begin{array}{c}\text { Transport costs } \\
(\%)\end{array}$ \\
\hline Within 10 km & 1 & 8.92 & 16.3 & 10.26 & 15.8 \\
\hline & & $\mathrm{A}$ & A & A & A \\
\hline From 10 to $30 \mathrm{~km}$ & 4 & $\begin{array}{c}10.91 \pm 0.90 \\
(\mathrm{~B}, \mathrm{a})\end{array}$ & $\begin{array}{c}31.2 \pm 5.62 \\
(B, a)\end{array}$ & $\begin{array}{l}12.49 \pm 1.01 \\
(\mathrm{~B}, \mathrm{a})\end{array}$ & $\begin{array}{c}30.6 \pm 5.60 \\
(\mathrm{~B}, \mathrm{a})\end{array}$ \\
\hline From 30 to $40 \mathrm{~km}$ & 11 & $\begin{array}{c}13.56 \pm 0.46 \\
(\mathrm{C}, \mathrm{a})\end{array}$ & $\begin{array}{c}44.8 \pm 1.84 \\
(\mathrm{C}, \mathrm{a})\end{array}$ & $\begin{array}{c}15.47 \pm 0.52 \\
(\mathrm{C}, \mathrm{b})\end{array}$ & $\begin{array}{c}44.1 \pm 1.80 \\
(\mathrm{C}, \mathrm{a})\end{array}$ \\
\hline From 40 to $60 \mathrm{~km}$ & 12 & $\begin{array}{c}17.66 \pm 0.28 \\
(\mathrm{D}, \mathrm{a})\end{array}$ & $\begin{array}{c}57.7 \pm 0.69 \\
(\mathrm{D}, \mathrm{b})\end{array}$ & $\begin{array}{c}20.08 \pm 0.31 \\
(\mathrm{D}, \mathrm{a})\end{array}$ & $\begin{array}{c}56.9 \pm 0.69 \\
(\mathrm{D}, \mathrm{a})\end{array}$ \\
\hline From 60 to $70 \mathrm{~km}$ & 13 & $\begin{array}{c}18.37 \pm 0.23 \\
(\mathrm{E}, \mathrm{a})\end{array}$ & $\begin{array}{c}59.3 \pm 0.50 \\
(\mathrm{E}, \mathrm{b})\end{array}$ & $\begin{array}{c}20.87 \pm 0.26 \\
(\mathrm{E}, \mathrm{b})\end{array}$ & $\begin{array}{c}58.6 \pm 0.54 \\
(\mathrm{E}, \mathrm{a})\end{array}$ \\
\hline More than $70 \mathrm{~km}$ & 16 & $\begin{array}{c}20.97 \pm 1.34 \\
(\mathrm{~F}, \mathrm{a})\end{array}$ & $\begin{array}{c}64.2 \pm 2.00 \\
(\mathrm{~F}, \mathrm{a})\end{array}$ & $\begin{array}{c}23.79 \pm 1.51 \\
(\mathrm{~F}, \mathrm{~b})\end{array}$ & $\begin{array}{c}63.5 \pm 2.02 \\
(\mathrm{~F}, \mathrm{a})\end{array}$ \\
\hline
\end{tabular}


$70 \mathrm{~km}$ from the power plant, the incidence of these is significantly, despite slightly, lower when harvesting is carried out according to the double phase system.

With reference to transport costs incidence on overall costs, these results fully comply with the finding of Spinelli et al. (2006), who assessed that transportation accounts for $30-50 \%$ of the total costs on the short haul, and $60-70 \%$ of the costs on the long one when SRF poplar for pulpwood is concerned. Nevertheless, when transport cost values are concerned, according with Sultana and Kumar (2011), both fixed costs and distance related variable should be considered with the latter depending on the type of biomass being transported, on the form of biomass, on the equipment used for loading-unloading and any existing contractual agreement (Searcy et al., 2007). Mahmudi and Flynn (2006) assessed the fixed costs of woody chips transport at 4.07 $€ \mathrm{t}^{-1}$ and the variable component at $0.06 € \mathrm{t}^{-1}$. Transport costs recalculation with these values (converted into euros) give rise to an great overestimation of transport costs for the production unit closer to the power plant, while for the other groups of biomass production sites the predicted values are $24 \%$ higher than ours in case of units ranging from, 10 to $30 \mathrm{~km}$ from the plant, while for all the others the estimated values are from 29 to $60 \%$ lower. This trend is confirmed also by comparing overall costs with those of $49.46 € \mathrm{t}^{-1}$ for $16 \mathrm{~km}$ distance and $36.33 € \mathrm{t}^{-1}$ for $27 \mathrm{~km}$ distance presented by Perrin (2012) who worked on corn-stover biomass supply of ethanol production facility. The reason of this can be ascribed, on one hand, to the costs of the fuel for transport which, has high impact on transport costs in the European context, while on the other to the high variability of duty trucks which can differ substantially around the world and even in the same country (Widerberg et al., 2006). Moreover, with reference to data provided by Perrin et al. (2012) their value is unavoidably affected by the higher value of fixed and variable components that, according to Kumar and Sokhansanj (2007), are quite higher than those provided by Mahmudi and Flynn (2006).

\section{Conclusions}

A case study on the effective costs related to biomass supply chain in the Emilia Romagna region was carried out considering a number of SRF production sites within $70 \mathrm{~km}$ of distance from the power plant. At increasing of the distance, overall cost can almost double passing, at varying of the hypothesized scenario, from $8.92-10.26 € \mathrm{t}^{-1}$ to 20.97 $-23.79 € \mathrm{t}^{-1}$ where transport costs incidence varies from 31 to $64 \%$.

\section{References}

Andersson G., Flisberg P., Lidén, B, Rönnqvist, M. 2008. RuttOpt - a decision support system for routing of logging trucks. Can J Forest Res 38 (7): 1784-1796.

Angus-Hankin C., Stokes B., Twaddle A. 1995. The transportation of fuel wood from forest to facility. Biomass Bioenerg 9 (1-5): 191-203.

Cherubini F., Strømman A.H. 2011. Life cycle assessment of bioenergy systems: State of the art and future challenges. Bioresource Technol 102 (2): 437-451.

Djomo S.N., Kasmioui O.E., Ceulemans R. 2011. Energy and greenhouse gas balance of bioenergy production from poplar and willow: a review. GCB Bioenerg 3: 181-197.

Dubuisson X., Sintzoff I. 1998. Energy and $\mathrm{CO}_{2}$ balances in different power generation routes using wood fuel from short rotation coppice. Biomass Bioenerg 15: 379-390.
Fiala M., Bacenetti J. 2012. Economic, energetic and environmental impact in short rotation coppice harvesting operations. Biomass Bioenerg 42: 107-113.

Frombo F., Minciardi R. , Robba M., Rosso F., Sacile R. 2009. Planning woody biomass logistics for energy production: A strategic decision model. Biomass Bioenerg 33 (3): 372-383.

Goldstein N. 2006. Woody biomass as a renewable energy source. Biocycle 47(11): 29-31.

González-García S., Bacenetti J., Murphy R.J., Fiala M. 2012. Present and future environmental impact of poplar cultivation in the Po Valley (Italy) under different crop management systems. J Clean Prod 26: 56-66

Jirjis R. 2001. Forest residue-effect of handling and storage on fuel quality and working environment. Forest Research Bulletin 223: 136-145.

Kumar A., Sokhansanj S. 2007. Switchgrass (Panicum virgatum L.) delivery to a biorefinery using integrated biomass supply analysis and logistics (IBSAL) model. Bioresource Technol 98: 10331044.

Lehtikangas, P. (2000). Storage effects on pelletised sawdust, logging residues, and bark. Biomass Bioenerg 19: 286-293.

Lehtikangas, P. (2001). Quality properties of pelletised sawdust, logging residues, and bark. Biomass Bioenerg 20: 351-360.

Mahmudi H., Flynn P.C. 2006. Rail vs Truck transport of biomass. Appl Biochem Biotech 129 (1-3): 88-103.

Masera 0., Ghilardi A., Drigo R., Trossero M.A. 2006. WISDOM: A GISbased supply demand mapping tool for woodfuel management. Biomass Bioenerg 30: 618-637.

Minitab ${ }^{\circledR} 16$ Statistical Software (2010). [Computer software]. State College, PA: Minitab, Inc. (www.minitab.com)

Mitchell C.P. 2000. Development of decision support systems for bioenergy Applications. Biomass Bioenerg 18: 265-278.

Noll M., Naumann A., Ferrero F., Malow M. (2010). Exothermic processes in industrial-scale piles of chipped pine-wood are linked to shifts in gamma-, alphaproteobacterial and fungal ascomycete communities. International Biodeter Biodegr 64, 29-637.

Noon C.E., Daly J.M. 1996. GIS-based biomass resource assessment with BRAVO. Biomass Bioenerg 10: 101-109.

Panichelli L., Gnansounou E. 2008. GIS-based approach for defining bioenergy facilities location: A case study in Northern Spain based on marginal delivery costs and resources competition between facilities. Biomass Bioenerg 32: 289-300.

Palmgren M., Rönnqvist M., Varbrand P. 2004. A near-exact method to solve the log truck scheduling problem. International Transactions in Operational Research, 11: 447-464

Pan F, Han H-S, Johnson L, Elliot W. 2008. Production and cost of harvesting and transporting small-diameter trees for energy. Forest Prod J 58 (5): 47-53.

Pettersson M., Nordfjell T. 2007. Fuel quality changes during seasonal storage of compacted logging residues and young trees. Biomass Bioenerg 31: 782-792.

Ranta, T. 2005. Logging residues from regeneration fellings for biofuel production-a GIS-based availability analysis in Finland. Biomass Bioenerg 28: 171-182.

Spinelli R., Nati C., Magagnotti N. 2006. Recovering logging residue: experiences from the Italian Eastern Alps. Croat J For Eng 28: 1-9.

Spinelli R., Hartsough, B.R. 2006. Harvesting SRF poplar for pulpwood: Experience in the Pacific Northwest. Biomass Bioenerg 30: 439445.

Stolarski, M.J., Szczukowski S., Tworkowski J., Klasa A. 2011. Willow biomass production under conditions of low-input agriculture on marginal soils. Forest Ecol Manag 262 (8): 1558-1566. 
Sultana, A., Kumar, A. 2011. Optimal configuration of multiple lignocellulosic biomass feedstocks delivery to a biorefinery. Bioresource Technol 102: 9947-9956.

Walle I.V., Camp N.V., Van de Casteele L, Verheyen K, Lemeur R. 2007. Short-rotation forestry of birch, maple, poplar and willow in Flanders (Belgium) II. Energy production and $\mathrm{CO} 2$ emission reduction potential. Biomass Bioenerg 31:276-283.
Widerberg J., Dahlber E., Svensson M. 2006. Study of stability measures and legislation of heavy articulated vehicles in different OECD countries. Conference proceedings/ISHVWD-9.

Zhan F.B., Chen X., Noon C.E., Wu. G. 2005. A GIS-enabled comparison of fixed and discriminatory pricing strategies for potential switchgrass-to-ethanol conversion facilities in Alabama. Biomass Bioenerg 28: 295-306. 